\title{
Biological functions of casein kinase 1 isoforms and putative roles in tumorigenesis
}

\author{
Birgit Schittek ${ }^{*}$ and Tobias Sinnberg ${ }^{*}$
}

\begin{abstract}
Isoforms of the casein kinase 1 (CK1) family have been shown to phosphorylate key regulatory molecules involved in cell cycle, transcription and translation, the structure of the cytoskeleton, cell-cell adhesion and receptor-coupled signal transduction. They regulate key signaling pathways known to be critically involved in tumor progression. Recent results point to an altered expression or activity of different CK1 isoforms in tumor cells. This review summarizes the expression and biological function of CK1 family members in normal and malignant cells and the evidence obtained so far about their role in tumorigenesis.
\end{abstract}

Keywords: Casein kinase 1, Tumor, Cancer, Melanoma, $\beta$-catenin, p53

\section{Introduction}

Protein kinases represent an important therapeutic target for drug development since they play a central role in signal transduction. By reversible phosphorylation of their substrate proteins, kinases exert influence on substrate activity, localization and function and thus play an essential role in almost all cellular processes. The casein kinases (CK) belong to the serine/threonine kinases and can be subdivided further into either casein kinase 1 (CK1) or casein kinase 2 (CK2) families due to their high homology in their catalytic domains [1]. This review focuses on the isoforms of the CK1 family, which have non-redundant and essential functions in cell survival and tumorigenesis [2].

In vertebrates, seven CK1 isoforms $(\alpha, \beta, \gamma 1, \gamma 2, \gamma 3, \delta$ and $\varepsilon$ ) and several splice variants for CK1 $\alpha, \delta, \varepsilon$ and $\gamma 3$ have been identified $[1,3]$. The CK1 $1 \beta$-isoform has only been found in cows. They differ in length and sequence of the N-terminal (9-76 amino acids) and especially the C-terminal (24-200 amino acids) non-catalytic domain (Figure 1). By this, the molecular weight of the various CK1 isoforms ranges from $37 \mathrm{kD}(\mathrm{CK} 1 \alpha)$ up to $51 \mathrm{kD}$ (CK1 $\gamma 3)$. The C-terminal domain plays a crucial role in substrate specificity and in the regulation of kinase activity [1,3-5]. The isoforms show a high homology, i.e. CK1 $\delta$

\footnotetext{
*Correspondence: birgit.schittek@med.uni-tuebingen.de; tobias.sinnberg@med.uni-tuebingen.de

Department of Dermatology, Division of Dermatooncology, University of Tübingen, Liebermeisterstr. 25, 72076 Tübingen, Germany
}

and CK1 $1 \varepsilon$ are $98 \%$ identical in their kinase domain and $53 \%$ identical in their C-terminal regulatory domain [6]. Therefore, there is some redundancy with respect to substrate phosphorylation - however, there are also examples of distinct biological roles for the different CK1 isoforms.

\section{Substrates and interaction partners of CK1 isoforms}

In recent years an increasing number of substrates have been identified that are phosphorylated by CK1 isoforms in vitro or in vivo $[1,4,5]$. Several known substrates especially of the CK1 $\alpha$ and $\delta$ isoforms are involved in oncogenic signaling pathways as $\mathrm{Wnt} / \beta$-catenin $(\beta$-catenin; dishevelled (DVL); adenomatous polyposis coli (APC); nuclear factor of activated T cells, cytoplasmic 3 (NFATC3)), p53 (p53; p53/E3 ubiquitin-protein ligase Mdm2 (MDM2)), PI3K/AKT (forkhead box protein O1 (Foxo1)), and death receptor signaling (Fas-associated death domain protein (FADD); BH3-interactive domain death agonist (BID)). In addition, various interaction partners have been identified from which it is not known yet whether they can serve as a CK1 substrate. These include proteins that are involved in cell cycle, apoptosis induction, DNA repair, mitochondrial function and signal transduction. Moreover, several proteins involved in oncogenic signaling pathways are predicted to interact with the different CK1 isoforms (Table 1). These proteins mainly belong to the Hedgehog (GLI), Hippo (MST, YAP), Wnt/ $\beta$-catenin (Axin, Dvl1-3, FZD1 and 5, GSK3, Wnt3A), NFKB (NFkBIA), TGF-beta/Smad (Smad3) or p53 (MDM2 and 4) -signaling pathways and 


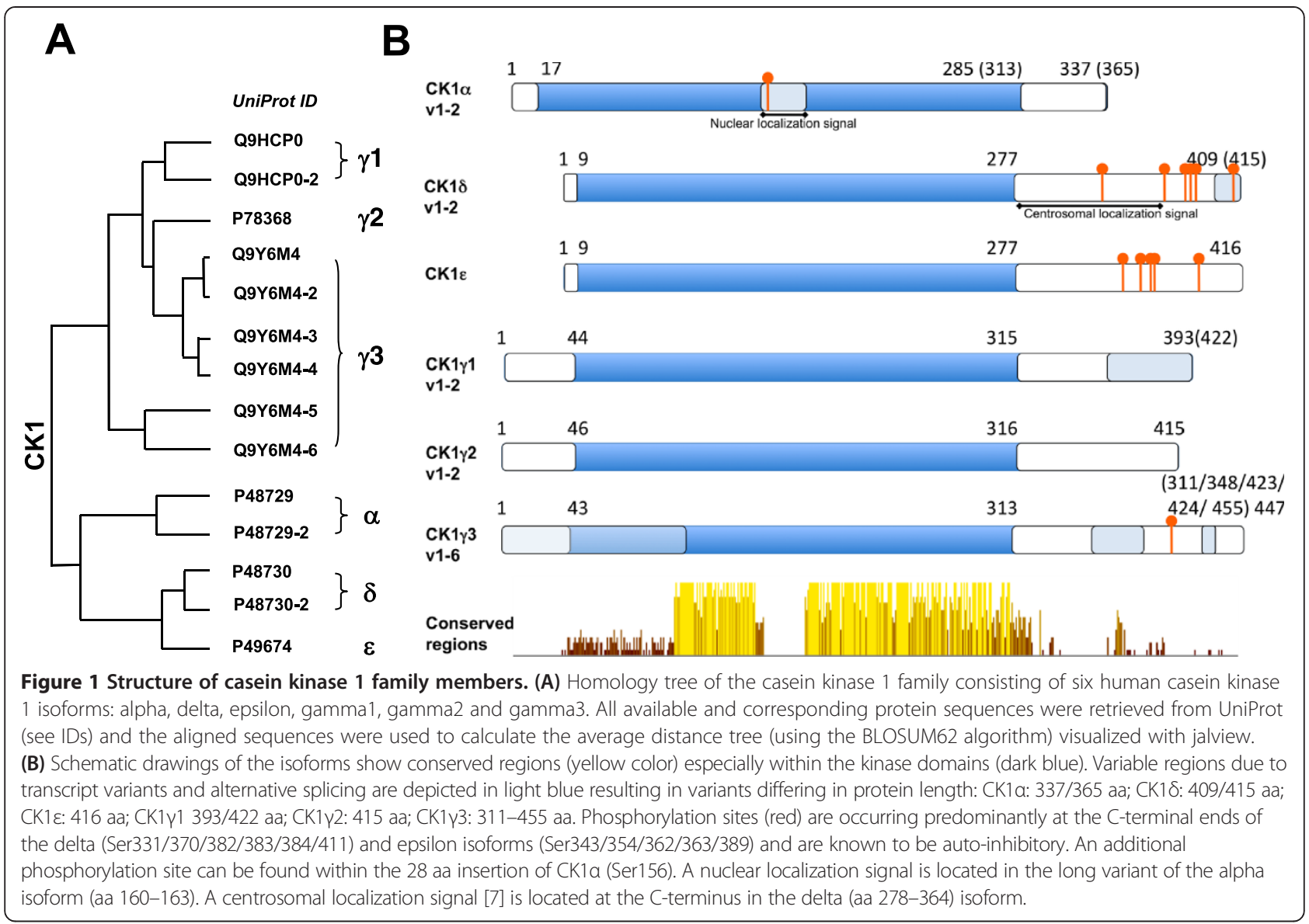

hence are involved in regulation of the cell cycle, apoptosis induction or cell survival. Many of these interactants are known to be deregulated in tumor cells and interaction with CK1 isoforms might trigger tumor initiation or progression [2].

A distinctive feature of CK1 family members is their exclusive need of ATP to phosphorylate their substrates and their independency of other co-factors. They show a strong preference for primed, pre-phosphorylated substrates [30]. Surprisingly, the substrate specificity defined in vitro differs from in vivo for the different CK1 family members [4] suggesting that the in vivo specificity is regulated by interaction partners, autophosphorylation or subcellular localization. Interaction with cellular proteins has been shown to be a major determinant of the localization of CK1 isoforms [31-35] and to either enhance or inhibit their activity $[12,13,36]$.

\section{Biological functions of CK1-isoforms}

The wide range of substrates shows that the CK1 family members are involved in multiple cellular processes. For example they are involved in the regulation of membrane trafficking, cytokinesis, vesicular transport, ribosome biogenesis, DNA repair, signal transduction pathways and in the circadian rhythm $[1,5,37]$. Up to now most evidence points to important regulatory roles of the isoforms CK $1 \alpha$, CK1 $\delta$ and CK1ع, while the role of the gamma-isoforms are still enigmatic and not very well investigated.

$C K 1 \alpha$ plays a role in the mitotic spindle formation during cell division and in DNA repair mechanisms and participates in RNA metabolism [1]. Antibodies specific for CK1 $\alpha$ block cell cycle progression during $M$ phase in mouse oocytes, which indicates that CK1 $\alpha$ is required for proper cell cycle progression in these cells $[38,39]$. CK1 $\alpha$ can be found at the centrosomes, microtubule asters and the kinetochore [40]. In addition, it was shown that mTOR cooperates with CK $1 \alpha$ to promote its own full activation via the sustained degradation of the endogenous mTOR inhibitor DEPTOR [41]. Similarly, CK1 $\alpha$ regulates apoptotic signaling pathways, however, there seems to be cell type-specific differences. CK1 $\alpha$ has been shown to have an anti-apoptotic function in the extrinsic apoptosis pathway. Its inhibition increased Fas-induced apoptosis in Hela cells, whereas the overexpression of CK $1 \alpha$ delayed cell death, caused by the phosphorylation of BID, which prevented the caspase 8 dependent cleavage of BID [9]. In addition, CK1 $\alpha$ inhibits TRAIL induced apoptosis by modification of the TNF receptor or FADD at the death- 
Table 1 CK1 interaction partners and substrates

\begin{tabular}{|c|c|c|c|c|c|}
\hline Protein & Description & $\begin{array}{l}\text { CK1 interaction } \\
\text { partners }\end{array}$ & $\begin{array}{l}\text { Known Phospho-rylation } \\
\text { sites }\end{array}$ & Cellular process & Reference \\
\hline $\mathrm{BCL} 10$ & B-cell CLL/lymphoma 10 & $a$ & & Apoptosis & [8] \\
\hline BID & $\mathrm{BH} 3$ interacting domain death agonist & $a, \delta$ & T59, S64 (a, 8) & Apoptosis & [9] \\
\hline FADD & Fas (TNFRSF6)-associated via death domain & a & $\mathrm{S} 194(\mathrm{a})$ & Apoptosis & {$[10]$} \\
\hline E2F1 & E2F transcription factor 1 & a & & Cell cycle & [11] \\
\hline Chk1 & Checkpoint kinase 1 & $\delta$ & & Cell cycle & {$[12]$} \\
\hline DDX3 & DEAD box RNA helicase & $\varepsilon$ & & DNA repair & [13] \\
\hline SPRY2 & Sprouty1 & $\delta, \varepsilon$ & & FGF-signaling & [14] \\
\hline GLI1-3 & GLI family zinc finger 1-3 & $a, \delta, \varepsilon, \gamma 1, \gamma 2, \gamma 3$ & & Hedgehog signaling & {$[15]$} \\
\hline ANT2 & Adenine nucleotide translocase 2 & $\varepsilon$ & & Mitochondrial function & [16] \\
\hline MST1 & Mammalian sterile 20-like kinase 1 & $\varepsilon$ & & Hippo signaling & {$[17]$} \\
\hline NFKBIA & $\begin{array}{l}\text { Nuclear factor of kappa light polypeptide } \\
\text { gene enhancer in B-cells inhibitor, alpha }\end{array}$ & a & & NFKB signaling & [18] \\
\hline P65 & NFKB subunit & $\gamma 1$ & S536 & NFKB signaling & [19] \\
\hline $\begin{array}{l}\text { MDM2 MDMX } \\
\text { (MDM4) }\end{array}$ & Mouse double minute 2 or 4 homolog & $a$ & & p53 signaling & [20] \\
\hline TP53 & Tumor protein p53 & $a, \delta, \varepsilon, \gamma 1, \gamma 2, \gamma 3$ & S6, S9 (a); T18 (8) & p53 signaling & [21] \\
\hline Foxo1 & Forkhead box 01 & $\delta, \varepsilon, \gamma 1, \gamma 2, \gamma 3$ & $\mathrm{~S} 322(\mathrm{a}, \mathrm{y} 1), \mathrm{S} 325(\mathrm{a})$ & PI3K/AKT signaling & [22] \\
\hline RAPGEF2 & Rap guanine nucleotide ex-change factor 2 & a & S1244, S1248 & Ras activation & [23] \\
\hline SMAD3 & SMAD family member 3 & $\gamma 2, \varepsilon$ & & TGF-beta/Smad signaling & [24] \\
\hline APC & Adenomatous polyposis coli & $a, \delta, \varepsilon$ & $\begin{array}{l}\text { all } \varepsilon: S 1279, \text { S1392, S1504, } \\
\text { S1505, S1507, S1510 }\end{array}$ & Wnt signaling & [25] \\
\hline AXIN1 AXIN2 & Axin 1 and 2 & $a, \delta, \varepsilon, \gamma 1$ & & Wnt signaling & [4] \\
\hline CTNNB1 & Beta-catenin & $a, \delta, \varepsilon$ & S45 $(a, \delta)$ & Wnt signaling & [4] \\
\hline NFATC3 & Nuclear factor of activated T-cells & a & $\begin{array}{l}\text { all a: T204, S207, T210, } \\
\text { S211, S215 }\end{array}$ & Wnt signaling & {$[26]$} \\
\hline DVL1-3 & Dishevelled, dsh homolog 1-3 & $\delta, \varepsilon, \gamma 1$ & & Wnt signaling & [4] \\
\hline CSNK1D & Casein kinase 1 , delta & $\varepsilon$ & & Wnt signaling & [4] \\
\hline FZD1 FZD5 & Frizzled homolog 1 or 5 & $\gamma 1$ & & Wnt signaling & [27] \\
\hline GSK3A GSK3B & Glycogen synthase kinase 3 alpha or beta & $\gamma 1$ & & Wnt signaling & {$[28]$} \\
\hline WNT3A & $\begin{array}{l}\text { Wingless-type MMTV integration } \\
\text { site family, member } 3 \mathrm{~A}\end{array}$ & $\gamma 1$ & & Wnt signaling & [29] \\
\hline
\end{tabular}

CK1 substrates are shown with known phosphorylation sites together with the involved cellular processes of the corresponding proteins. The following programs were used for determination of interaction or phosphorylation: string-db.org, hprd.org; regphos.mbc.nctu.edu.tw, www.phosphosite.org. Only proteins validated by biochemical assays are shown.

inducing signaling complex (DISC) [42]. Therefore downregulation of CK1 $\alpha$ leads to an enhancement of TRAILinduced cell death. Likewise, CK1 $\alpha$ promotes cell survival by interacting with the retinoid X receptor (RXR). Downregulation of CK1 $\alpha$ enhances the apoptotic effect of RXR agonists [43]. In contrast, overexpression of CK1 $\alpha$ in metastatic melanoma cells induces apoptosis [44].

In addition to the regulatory function in apoptosis signaling pathways, CK $1 \alpha$ is involved in the phosphorylation of G-protein coupled receptors (GPCRs) such as the M3 and M1 muscarinic receptors and rhodopsin [45]. These become phosphorylated by CK1 $\alpha$ upon agonist-induced desensitization $[45,46]$. Furthermore, CK1 $\alpha$ is involved in the phosphorylation of NFAT4 (nuclear factor for activated $\mathrm{T}$ cells 4), so that its nuclear localization signal is masked and thus the activity of the transcription factor is inhibited $[47,48]$. Recently, it was shown in epithelial cells that in response to factors promoting cell motility, CK $1 \alpha$ in conjunction with IKK $\beta$ phosphorylate the Rap guanine exchange factor 2 (RAPGEF2) leading to its degradation by the proteasome which was shown to be essential for the invasion of breast cancer cells [23].

$C K 1 \delta$ and $C K 1 \varepsilon$ are known to be important regulators in the circadian rhythm of eukaryotic cells. The central clock genes period circadian protein homolog 1-3 (PER1-3) cycle in a daily rhythm. Cytoplasmic PER is phosphorylated by CK1, which induces its degradation [49]. When PER is in a complex with cryptochrome (CRY), the phosphorylation 
site is masked and the complex together with CK1 translocates to the nucleus where it represses another clock transcription factor complex (the BMAL1/Clock complex) and inhibits the transcription of most of the clock genes. Additionally, CK1 $\alpha$ was identified as a negative PER1 regulator similar to the CK1 $\delta$ isoform [50], however the binding of $\mathrm{CK} 1 \delta$ and $\varepsilon$ to PER proteins seems to be much stronger than CK1 $\alpha$ [50]. Pharmaceutical inhibition of CK1 $\varepsilon$ was less effective compared to pan $\mathrm{CK} 1 \delta / \varepsilon$ inhibitors in prolonging the circadian rhythm [51] proposing a dominant role of CK1 $\delta$ in the regulation of daily oscillating processes. Taken together CK1s are important regulators of the circadian rhythm [52,53]. Meanwhile it is known that CK1 $\delta$ is involved in the regulation of cell cycle progression and it was recently shown that checkpoint kinase 1 (Chk1) is able to interact and specifically phosphorylates CK1 $\delta$ and by this regulates the kinase activity [12]. Additionally, CK1 $\delta$ interacts with the spindle apparatus and regulates phosphorylation of $\alpha-, \beta-$, and $\gamma-$ tubulin $[35,54,55]$. It seems to be essential for microtubule nucleation at the golgi [56]. Besides tubulin phosphorylation CK $1 \delta$ mediates the phosphorylation of microtubule associated proteins (MAPs), stathmin and tau thereby regulating the dynamics of the microtubule and spindle apparatus [34,35,57-59]. Recently, it was shown that CK1 $\delta$ mediates the phosphorylation of Sid4 an important cytokinesis regulator [60] strengthening the important function of CK1 $\delta$ in cell proliferation. As CK1 $\delta$ and Chk1 are known to inhibit p53 via phosphorylation, pharmacological inhibition of both kinases resulted in activation of p53 similar to the effect of the MDM2 inhibitor nutlin-3 [61]. CK1 $\delta$ and CK1 $\varepsilon$ are able to interact with Sprouty2 (SPRY2), which is a potent negative regulator of fibroblast growth factor (FGF) receptor tyrosine kinase signaling. CK1 activity and binding are necessary for SPRY2 mediated inhibition of FGFstimulated neurite outgrowth and FGF-dependent RAS activation via GRB2/SOS [14]. It was further shown that CK1 $\delta$ and CK1 $1 \varepsilon$ are required for the biogenesis of small ribosomal subunits and for the functionality of $40 \mathrm{~S}$ ribosomal subunits in protein translation [37].

\section{The role of CK1 isoforms in Wnt/ $\beta$-catenin signaling}

The CK1 isoforms CK1 $\alpha, C K 1 \delta$ and CK1 $1 \varepsilon$ have a common regulatory function in the $\mathrm{Wnt} / \beta$-catenin signaling pathway and act in a concerted manner [2]. Dishevelled (Dvl), a key component in the Wnt/ $\beta$-catenin signaling pathway, becomes phosphorylated by $C K 1 \delta / \varepsilon$ upon pathway activation by Wnts [62]. Recent evidence indicates that there is a coordinated action of the different CK1 isoforms to activate Wnt/ $\beta$-catenin signaling in colon adenocarcinoma cells [29]. In these cells CK1 $1 \varepsilon$, but not $\mathrm{CK} 1 \alpha$ is required for the early response to Wnt3a stimulation. The two protein kinases function sequentially: CK1 $1 \varepsilon$ is bound to p120-catenin and E-cadherin and is required for early responses to Wnt3a stimulation, such as recruitment of Dishevelled 2 (Dvl-2), followed by the phosphorylation of the Wnt co-receptors LRP $5 / 6$ by $\mathrm{CK} 1 \gamma$ which leads to the recruitment of axin complexed with CK1 $\alpha$. CK1 $\alpha$ then phosphorylates p120-catenin and E-cadherin causing a release of $\mathrm{p} 120$-catenin/E-cadherin from the complex, and dissociation of CK1ع from p120 which terminates the input signal. For pathway inactivation $\beta$ catenin has to become $\mathrm{N}$-terminally phosphorylated. In order to be phosphorylated by GSK3 $\beta$ at the Ser residues 33,37 and $41, \beta$-catenin must first get primed by phosphorylation on Ser45 by CK $1 \alpha[63,64]$. Without priming phosphorylation by CK $1 \alpha$, GSK $3 \beta$ does not phosphorylate $\beta$-catenin and therefore $\beta$-catenin is not degraded. A down-regulation of CK $1 \alpha$ thus leads to an accumulation of cytoplasmic $\beta$-catenin [44]. In mouse embryonic stem cells DNA damage and its response (DDR) causes an activation of the canonical Wnt signaling by reduced $\mathrm{CK} 1 \alpha$ expression levels. The Wnt signaling was shown to limit the p53 dependent apoptosis induction after DDR indicating a pro-survival effect of Wnt signaling [65]. Recently, the DEAD-box RNA helicase DDX3 was identified as a regulator of the $\mathrm{Wnt} / \beta$-catenin signaling pathway by acting as a regulatory subunit of CK1 $1 \varepsilon$ in a Wnt-dependent manner. It binds to $C K 1 \varepsilon$, directly stimulates its kinase activity, and promotes phosphorylation of the scaffold protein dishevelled [13]. Furthermore CK1 $\varepsilon$ is known to phosphorylate adenomatosis polyposis coli (APC) together with GSK3 $\beta$ which leads to an increased affinity of APC to $\beta$-catenin causing a transfer of $\beta$-catenin from axin to APC. This exposes $\beta$-catenin to the $\beta$-TrCP ubiquitin ligase marking it for its proteasomal degradation $[25,66]$. Additionally $\mathrm{CK} 1 \delta$ is capable to regulate the canonical Wnt signaling on the level of lymphoid enhanced binding factor 1 (Lef-1). Lef-1 is phosphorylated by CK $1 \delta$ resulting in the disassembly of the $\beta$-catenin/Lef- 1 transcription factor complex thereby inhibiting the pathway [67].

\section{The role of CK1 isoforms in p53 signaling}

The tumor suppressor protein p53 as well as the p53 interacting proteins MDM2 and MDMX - both capable to regulate p53 activity by inhibitory interaction - are substrates of CK1 isoforms. The three CK1 isoforms $\mathrm{CK} 1 \alpha, \mathrm{CK} 1 \delta$ and $\mathrm{CK} 1 \varepsilon$ are capable to N-terminally phosphorylate the p53 in vitro and in vivo resulting in activation of $\mathrm{p} 53$. Furthermore, CK1 $\delta$ can phosphorylate MDM2, which leads to a reduced interaction with p53 and thus to stabilization and activation of p53 [68-70]. These data suggest that increased expression or activation of CK $1 \alpha$ or CK $1 \delta$ are able to activate p53 and by this increase cell cycle arrest and apoptosis induction. However, there are differences in the ability of the CK1 isoforms to either activate [70] or inactivate p53 [68,69] activity depending on the cell types used or the experimental 
conditions. Knockdown or downregulation of CK1 $\alpha$ in the intestinal epithelium of mice [71], in human colon cancers [72] or in leukemia cells [73] triggers p53 activation. Similarly, one study showed that CK1 $\alpha$ stably associates with MDMX, stimulates MDMX-p53 binding, and cooperates with MDMX to inactivate p53 [20]. These data suggest that inhibition of CK $1 \alpha$ activity increases p53 activity. Indeed, knockdown of CK $1 \alpha$ induces p53 transcriptional activity by reducing the inhibitory effect of MDMX for p53 [74] since MDMX phosphorylation is necessary for interaction with p53. Furthermore, knockdown of CK1 $\alpha$ reduces the interaction of MDM2 with p53 thus increasing p53 activity [11].

Under stress conditions and when CK1 is highly expressed the situation differs: p53 is activated by an autoregulatory loop between p53 and either CK1 $\alpha$ or CK1 $\delta$. CK1 $\alpha$ stimulates $\mathrm{p} 53$ probably by direct phosphorylation of Thr18 and Ser20 [5,75]. Thereby, CK $1 \alpha$ could be a cellular fine-tuning tool for the regulation of p53 activity. It was shown that after genotoxic stress it comes to a transcriptional activation of CK1 $\delta$ by p53 [68]. Furthermore, DNA damage activates $\mathrm{p} 53$ in part by disrupting CK1 $\alpha-M D M X$ interaction and reducing MDMX-p53 binding affinity [20]. In addition, DNA damage leads to an enhanced interaction between $\mathrm{CK} 1 \delta / \varepsilon$ and MDM2 resulting in multisite phosphorylation of MDM2 by CK1 and enhanced MDM2 degradation and subsequently enhanced p53 activity. Inactivation of CK1 (primarily $\mathrm{CK} 1 \delta$ or $\varepsilon$ and to a lesser extent $\mathrm{CK} 1 \alpha)$ results in accumulation of MDM2, thus decreased p53 activity and resistance to apoptosis induced by DNA damaging agents [76]. In conclusion, depending on the cell system used, CK1 $\alpha$ and CK1 $\delta$ are able to either increase or decrease p53 activity by direct phosphorylation or modulating the activity of the p53 interacting proteins MDM2 and MDMX. Furthermore, the activity of p53 as well as $\mathrm{CK} 1 \alpha$ and $\mathrm{CK} 1 \delta$ is increased under stress conditions pointing to an autoregulatory loop between CK1 isoforms and $\mathrm{p} 53$.

\section{Regulation of the expression and activity of CK1 isoforms}

The expression and activity of CK1 family members seems to be tightly regulated. Protein expression levels can be found at www.proteinatlas.org. Surprisingly, not much is known concerning the mechanisms involved in regulating CK1 expression and kinase activity until now. The expression of CK1 $\alpha$ can be down-regulated by the miRNA miR-155 [77]. Treatment of cells with insulin, topoisomerase inhibitors, irradiation or viral transformation is able to increase CK1 activity [1]. The subcellular localization of the CK1 isoforms is mainly regulated by binding to intracellular structures or protein complexes and thereby plays a role in substrate-recognition and CK1 activity [32-35,37,55]. Studies on the circadian rhythm in mice showed that the nuclear localization of CK1 $\delta$ and CK1 $\varepsilon$ is regulated during the day [78].

Posttranscriptional mechanisms are involved in the regulation of $\mathrm{CK} 1 \alpha$ activity. In Hela cells two CK $1 \alpha$ transcripts have been described which result from alternative splicing $[79,80]$. The short $2.4 \mathrm{kB}$ transcript originates from the larger $4.2 \mathrm{kB}$ transcript due to the use of an alternative polyadenylation site. Interestingly, the longer transcript has six adenine uridine rich element (ARE) motifs in the 3'-untranslated region (in the short transcript there is only one ARE-motif), which lead to increased RNA degradation of the $4.2 \mathrm{kB}$ transcript. Moreover, the long transcript harbors the above mentioned insertion of 84 bp or 28 amino acids in the catalytic domain, which also causes a change in substrate affinity [79]. Only the long splice variants of CK1 $\alpha$ have a nuclear localization sequence (PVGKRKR), which is responsible for the transport of CK1 $\alpha$ into the nucleus [81].

The activity of CK1 isoforms can also be regulated by post-translational modifications, in particular phosphorylations or proteolytic processing. For CK $1 \delta$ and CK $1 \varepsilon$ it was shown that the C-terminal domain is autophosphorylated, which inhibits the kinase activity [82-84]. As mentioned earlier, CK1 $1 \varepsilon$ is activated after Wnt3a stimulation by the removal of inhibitory C-terminal phosphorylations. The responsible phosphatases are not identified yet. Furthermore, part of the C-terminal domain can be cleaved, which increases kinase activity [1]. In addition, the three dimensional structure of CK $1 \delta$ plays a role in the regulation of activity. CK1 $\delta$ forms dimers leading to an inhibition of kinase activity [85].

Allosteric regulatory mechanisms were recently identified by two working groups and seem to be major determinants of CK1 kinase activity. Cruciat et al. showed that ATP-dependent RNA helicase DDX3X (DDX3) binds to $\mathrm{CK} 1 \varepsilon$ thereby allosterically activating the kinase domain and triggering canonical Wnt signaling. Using biochemical methods this novelty in kinase regulation was extended to the isoforms alpha, delta and gamma2 [13]. It is estimated that different DDX proteins can allosterically activate these CK1 isoforms (up to five fold). In line with these findings was the identification of the CK1 $\alpha$ activating drug pyrvinium. This anthelmintic can bind to all CK1 isoforms but activates only CK1 $\alpha$ due to conformational changes, thereby strongly inhibiting canonical Wnt signaling [86].

\section{CK1 Isoform expression and tumorigenesis}

The evidence obtained in recent years emphasizes the importance of CK1 isoforms in cancer progression in different types of tumors [2]. Microarray database analyses from tumor cell lines (http://discover.nci.nih.gov/ cellminer/analysis.do) and tissues (http://www.broadinstitute. org/cancer/software/genepattern/datasets/;Ramaswamy 
Multi-cancer) indicated that the CK1 $\delta$ and CK1 1 isoforms are overexpressed on RNA level in many tumor types. This includes cancers of bladder, brain, breast, colorectal, kidney, lung, melanoma, ovarian, pancreatic, prostate and the hematopoetic system. Expression of the CK1 1 1-3 isoforms seems to be rather low in different cancers types (Figure 2A, B). In addition, it has been shown that CK1 $\delta$ is overexpressed in cells of hyperplastic B cell follicles and B cell lymphomas in p53 deficient mice [87]. In renal cell carcinoma increased CK1 $\gamma 3$ expression was found [88]. In choriocarcinoma an increased expression of CK1 $\delta$ [55] and in ductal adenocarcinomas of the pancreas an increased expression of CK $1 \delta$ and CK $1 \varepsilon$ was detected [89]. A tabulary overview can be found in the recent review of Knippschild et al. [90].

RNA expression of CK1 $\alpha$ is more variable with high expression in cancers of the brain, prostate, lymphoma and especially in leukemia (Figure 2A, B). In bladder cancer, lung cancer and melanoma there is a trend to decreased RNA expression of CK1 $\alpha$ (Figure 2A, B). Expression analysis of $\mathrm{CK} 1 \alpha$ in melanoma datasets of the oncomine.org expression database clearly revealed a reduction in mRNA expression during melanoma progression. We confirmed the reduction of CK1 $\alpha$ expression

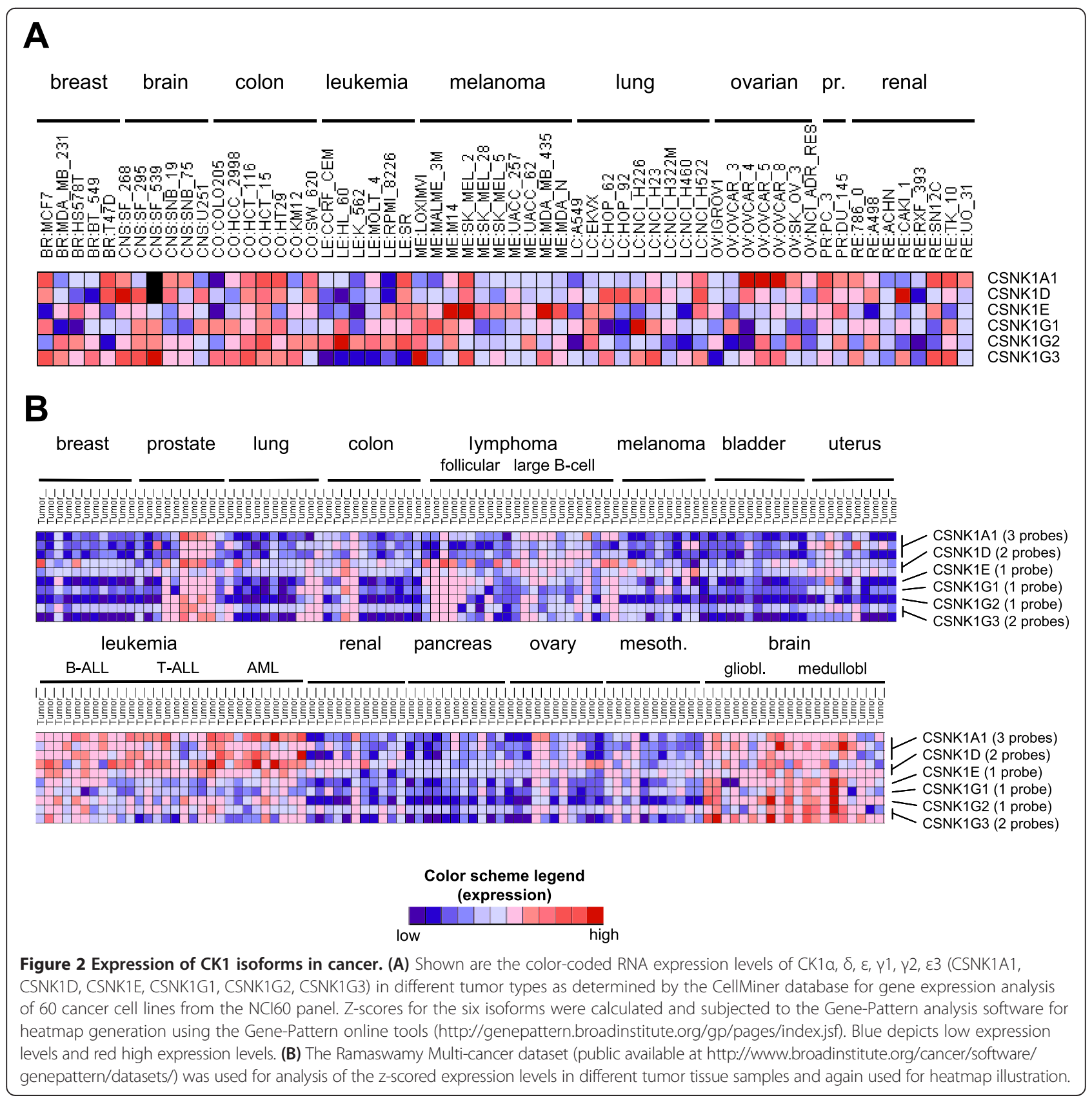


on protein level [44]. The downregulation of CK1 $\alpha$ expression in progressed melanoma tumors seems to be mainly mediated by promoter methylation of the CK $1 \alpha$ gene [44]. In contrast, there is one recent report claiming that CK $1 \alpha$ expression is higher in melanoma compared to benign nevi [91].

The expression data suggests that there are tumor-cell specific differences in the functional activities and/or relevance of CK1 isoforms in cancer. However, to gain information about the relevance of the different CK1 isoforms in tumor progression, the CK1 protein expression as well as the kinase activity should be determined since it is known that CK1 activity is regulated by posttranscriptional mechanisms and posttranslational modifications (see above). Several CK1- substrates (see Table 1) are known to play a role in tumorigenesis and are substrates of different CK1-isoforms. Therefore it will be important to clarify the redundancy in the activity of different CK1 isoforms. Furthermore, the mechanisms regulating CK1 expression and activity in tumor cells are still not well understood. Despite promoter methylation [44] mutations could play a regulatory role. In breast carcinoma, mutations were found in the coding region of the $\mathrm{CK} 1 \varepsilon$ gene [92]. In colonic adenoma, R324H mutations are described in the CK1 $\delta$ gene, and these were correlated with an increased oncogenic potential of the lesions including a higher transformation potential in vitro [93]. Interestingly, the $\mathrm{R} 324 \mathrm{H}$ mutation did not significantly alter the CK1 $\delta$ kinase activity or the Wnt/ $\beta$-catenin signaling activity in vitro but had strong impact on the morphological movement like secondary axis formation in Xenopus embryos. Mutations in CK1 isoforms seems to be rare, however, copy number variations seem to be more frequent (see http://cancer.sanger.ac.uk/cosmic). Analysis of the actual datasets of the cancer genome atlas (TCGA) available at the cBioPortal for Cancer Genomics [94,95] revealed the mutation pattern and copy number alterations (CNA) in 24 different tumor types (Figure 3). The total alteration frequency including CNAs and mutations is generally rather low ranging from $4.8 \%$ in clear cell renal cell carcinoma (ccRCC) for CSNK1A1 over 9.5\% in liver cancer for CSNK1D to 3.8\% for CSNK1E in melanoma tumors. Specific point mutation frequencies are even lower and do not exceed 2.4\% (as for CSNK1A1 in bladder cancer, for CSNK1D in lung squamous carcinoma and colorectal or pancreatic cancer; point mutations in CSNK1E seem to be very rare). Moreover the distribution of the detected mutations along the primary structure of the CK1 isoforms shows no accumulation in certain domains or regions which excludes the occurrence of hotspot mutations like in BRAF or TP53 (Figure 3A). Therefore genomic alterations of CK1 isoforms which lead to functional hyperactivity or defects may occur, however they seem to be seldom events.

\section{Functional role of CK1 isoforms in tumor progression}

What are the functional consequences of deregulated CK1 expression in tumor cells? On a functional level it was reported that CK1 $1 \varepsilon$ enhances the $\beta$-catenin-dependent proliferation in breast cancer [97]. However, it was recently shown that patients with oral cancers who had a loss of CK1 $1 \varepsilon$ expression had a poorer overall survival rate than patients who expressed CK $1 \varepsilon$ [98]. For CK1 $\delta$ it was shown that a point mutation in the $\mathrm{C}$-terminal regulatory domain of $\mathrm{CK} 1 \delta(\mathrm{R} 342 \mathrm{H})$ promotes the emergence of colorectal adenomas independent of Wnt-/ $\beta$-catenin [93]. In contrast, a downregulation of CK $1 \delta$ and $\varepsilon$-isoforms induced cell cycle arrest and apoptosis in a variety of tumor cell lines of different origin. These effects were also Wnt/ $\beta$-catenin-independent, but dependent on activated RAS and inactive p53 $[5,99]$. It was also shown that impaired CK $1 \delta$ activity attenuates SV40-induced cellular transformation in vitro and mouse mammary carcinogenesis in vivo [100]. Thus, depending on the experimental setup and the tumor type CK1-isoforms seems to have a specific and nonredundant role in tumorigenesis, however the results are often contradictory. One reason might be that CK1 isoforms have also a regulatory function, which is independent of the kinase activity. It was described that CK1 $1 \varepsilon$ can interact with mitochondrial proteins in ovarian cancer cells and by this, increase growth and survival of the tumor cells in a Wnt/ $\beta$-catenin independent manner [16].

Until now most hints pointing to an important role in tumor progression have been described for CK $1 \alpha$. Our own previous work support the observation that CK1 $\alpha$ in comparison to the other CK1 isoforms have a dominant and non-redundant function in metastatic melanoma cells [44]. We identified CK1 $\alpha$ as a novel tumor suppressor and a key regulator of $\beta$-catenin signaling in melanoma cells. Knockdown of CK $1 \alpha$ in primary melanoma cell lines significantly enhanced the invasive capacity of melanoma cell lines in vitro. This pro-invasive effect after CK $1 \alpha$ knockdown was reversible by inhibition of $\beta$ catenin signaling, demonstrating the dependence of the invasive phenotype on $\beta$-catenin in melanoma cells. Moreover, knockdown of CK $1 \alpha$ in a melanoma xenograft model using melanoma cells with low intrinsic tumorigenic potential strongly increased tumorigenicity and stabilized $\beta$-catenin [101]. In line with, one study showed that a pharmacological increase of CK $1 \alpha$ protein level and thereby a destabilization of activated $\beta$-catenin significantly diminished melanoma cell migration [102]. Interestingly Chien et al. found high $\beta$-catenin levels to be rather a good prognostic marker in melanoma as well as to inhibit invasion probably by the promotion of differentiation in conjunction with MITF [103,104]. In another recent study Chien et al. described a bad overall survival of BRAF inhibitor treated patients with tumors expressing high $\beta$-catenin protein levels. This reveals 


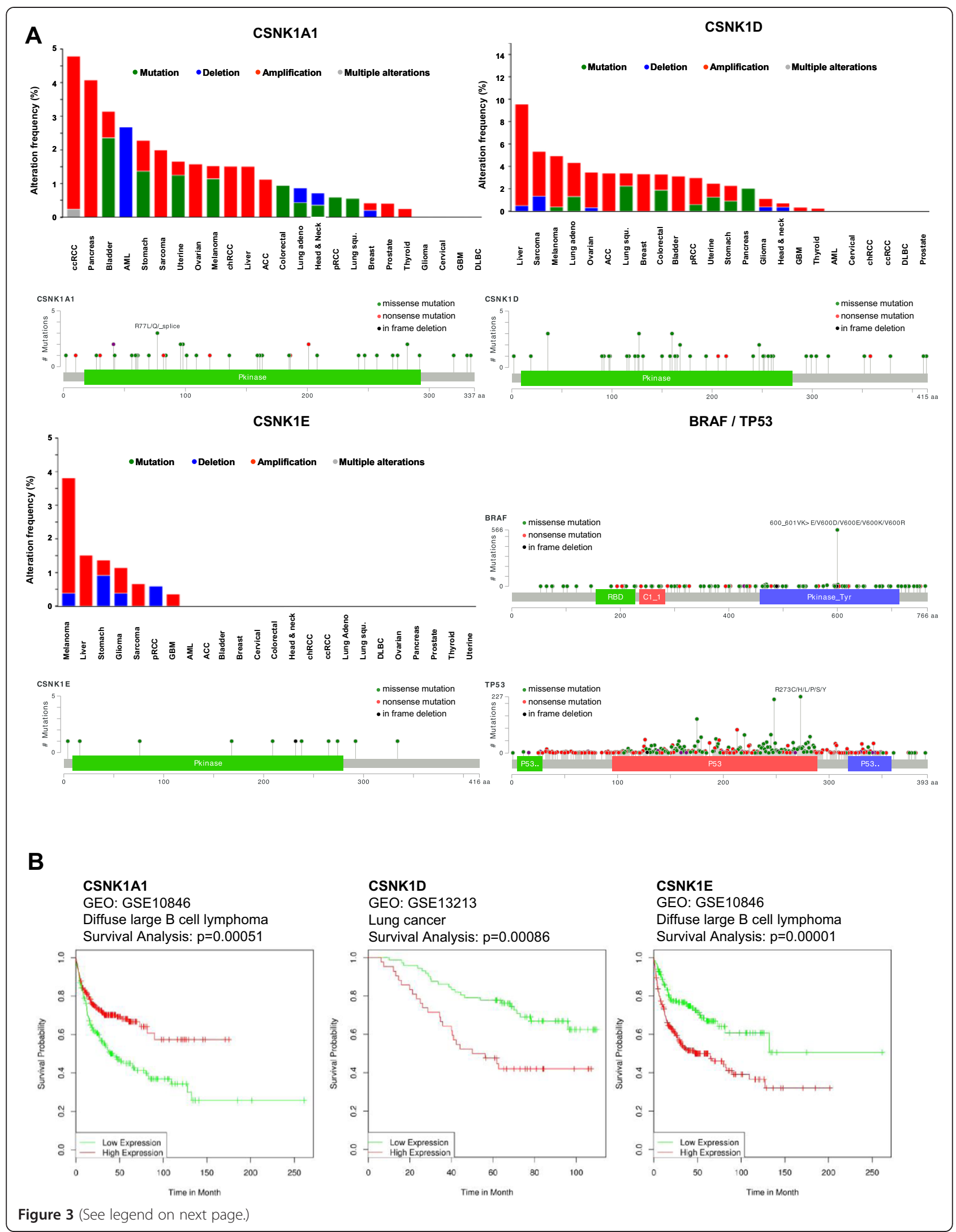


(See figure on previous page.)

Figure 3 Mutations in CK1 isoforms and cancer patient survival. (A) Mutation analysis of CK1 isoforms and overall survival of tumor patients stratified in CK1 isoform expression classes. 24 different tumor entities were analyzed using the cBioPortal for Cancer Genomics [94,95] accessing the newest TCGA datasets. The highest mutation frequency for CK1 a was detected in clear cell renal cell carcinoma (ccRCC) with approx. 4.8\%, for $C K 1 \delta$ in liver cancer with approx. 9.5\% and for CK1 $\varepsilon$ with approximately 3.8\% (top diagrams). The distribution along the primary structure of the three CK1 isoforms $a, \delta$ and $\varepsilon$ was analyzed in the cBioportal using all available datasets ( 69 cancer studies containing data of 17584 tumor samples). No hotspot mutation could be identified and only very low mutation frequencies were found (bottom diagrams). In comparison, analysis of the oncogene BRAF and the tumor suppressor TP53 revealed high mutation frequencies and the hot spot mutations at BRAFV600D/E/ K/R or TP53R273C/H/L/P/S/Y. (B) Survival analysis of stratified cancer patients into high and low CK1 isoform expression (determined by microarray gene expression analysis) was performed using the PPISURV online tool [96]. The studies showing the highest significant differences in overall survival (OS) between CK1 high and CK1 low patients are shown as Kaplan Meier curves for the $a, \delta$ and $\varepsilon$ isoforms (CK1 high expression in red, CK1 low expression in green).

that the different results probably refer to different, so far non-identified melanoma subtypes [105].

Furthermore, the activation of CK1 $\alpha$ kinase by the above mentioned allosteric activator pyrvinium induces cell death in colon carcinoma cell lines [86]. However, pyrvinium was recently described to elicit cytotoxicity in a CK1 independent manner by AKT downregulation and GSK3 activation in $293 \mathrm{~T}$ cells [28] and it is known to inhibit the unfolded protein response by GRP78 suppression [106] as well as cancer cell protective autophagy [107]. During melanoma progression CK1 $\alpha$ expression is lost and is not necessary for survival and cell cycle progression in metastatic melanoma cells. Overexpression of CK1 $\alpha$ retarded proliferation of metastatic melanoma cells and induced cell death, whereas the primary melanoma cell lines were mostly unaffected in their cell growth. This is consistent with the data showing that re-expression of CK1 $\alpha$ in the lung cancer cell line A549 in which the expression of CK1 $\alpha$ is also low causes reduced cell proliferation in vitro and tumor growth in vivo [108]. Our results suggest that the effect of $C K 1 \alpha$ on proliferation and invasion of melanoma cells in different stages of growth is at least partly due to an effect on the Wnt/B-catenin signaling pathway $[44,101]$.

The effect of CK1 $\alpha$ on tumor progression seems to be also dependent on the activity of the tumor suppressor p53. One study shows that loss of CK1 $\alpha$ in the intestinal epithelium of mice leads to hyperproliferation but not to tumor development. An additional inactivation of the p53 tumor suppressor gene or its target p21 is necessary to ensure the emergence of high-invasive colorectal tumors [71]. This suggests a non-redundant and dominant role of CK1 $\alpha$ compared to the other CK1 isoforms not only in melanoma, but also in colorectal tumorigenesis. Moreover expression levels of CK1 $\alpha$ seem to be a predictive survival marker in colon cancer patients with non-functional p53. Low CK1 $\alpha$ expression levels were shown to correlate with poor survival rates and a significant hazard ratio of 4.7 hinting at a pro-oncogenic function of loss-of-CK1 $\alpha$ on a p53 deficient background [72]. Furthermore, CK1 $\alpha$ knockdown as well as additional inactivation of p53 is necessary for tumors to progress. If p53 is present, tumor cells will be eliminated by cell cycle arrest or apoptosis. This assumption was verified recently in acute myeloid leukemia, where it was shown that inhibition of CK $1 \alpha$ has only a therapeutic effect, when p53 is active [73].

In the concept of tumorigenesis oncogenes play a pivotal role. However, excessive proliferative signaling as well as sustained DNA damage response can trigger cell senescence, commonly associated with a senescenceassociated secretory phenotype (SASP). The secreted proteins include proinflammatory chemokines and tissue remodeling factors that have on the one hand an autocrine, senescence reinforcing effect and on the other hand a paracrine effect on neighbouring cells, leading to bystander senescence and immune cell recruitment. Interestingly, in cancer, SASP can increase proliferation and invasion of tumor cells or induce angiogenesis. Another recently described pattern of secreted proteins from senescent cancer cells can be subsumed as senescentinflammatory response (SIR) resulting in a cell-autonomous initiation of inflammation, causing colonic tumor progression in a p21 deficient background. Usually, knockdown of CK1 $\alpha$ induces p53/p21 mediated arrest and a senescent phenotype in p53 functional cells [71]. The group of BenNeriah found out that in p53 (or p21) deficient murine gut tumor cells the SIR factors that occur after CK1 $\alpha$ knockdown induce pro-invasive genes like PROX1 thereby causing highly aggressive and hyperproliferative tumor cells. The described effect was highly dependent on the inflammatory response itself [109]. This shows that CK1 $\alpha$ is a negative regulator of the SIR and loss of CK1 $1 \alpha$ causes oncogene-like chronic stress which induces a prooncogenic switch to cell-autonomous, tumor promoting inflammation when p53 is inactivated.

In order to show the impact of CK1 isoforms on tumor progression we analyzed the survival of different cancer patients (17 types of cancer) depending on the gene expression levels of the three CK1 isoforms $\alpha, \delta$ and $\varepsilon$ using the PPISURV database [96], This database includes 45 expression studies with approximately 8000 patient survival data sets. Analysis revealed after stratification of the patients into the two classes high and low 
CK1 $\alpha$ expressing tumors a significant correlation between prolonged overall survival (OS) and high expression levels for 12 (B cell lymphoma, breast cancer, leukemia and lung cancer) out of 17 studies, whereas in
5 studies (lung cancer, colon cancer and liposarcoma) patients with high expression levels did worse. For CK1 $\delta$ there was positive correlation between high expression and longer survival in 6 (breast cancer, leukemia and

Table 2 Survival data from the PPISURV database showing correlations of CK1 gene expression and overall survival (OS) of cancer patients

\begin{tabular}{|c|c|c|c|c|}
\hline \multicolumn{5}{|c|}{ Survival profile of CSNK1A1 across available datasets with (with $p<0.05$ ) } \\
\hline GEO dataset & Cancer type & GENE (Probe ID) & P-value & Effect sign \\
\hline GSE10846 & Diffuse large b cell lymphoma & 206562_S_AT & 0.00051 & Positive \\
\hline GSE25065 & Breast cancer & 208865_AT & 0.000669 & Positive \\
\hline GSE25055 & Breast cancer & 206562_S_AT & 0.00141 & Positive \\
\hline GSE11121 & Breast cancer & 208867_S_AT & 0.00174 & Positive \\
\hline GSE39671 & Chronic lymphocytic leukemia & 226920_AT & 0.0021 & Positive \\
\hline GSE7390 & Breast cancer & 208867_S_AT & 0.00576 & Positive \\
\hline GSE13213 & Lung cancer & A_24_P251899 & 0.00715 & Negative \\
\hline GSE24080 & Multiple myeloma & 208865_AT & 0.00736 & Positive \\
\hline GSE22762 & Chronic lymphocytic leukemia & 208866_AT & 0.0119 & Positive \\
\hline GSE2034 & Breast cancer & 206562_S_AT & 0.0167 & Positive \\
\hline GSE31210 & Lung cancer & 208866_AT & 0.0179 & Positive \\
\hline GSE3494 & Breast cancer & 208866_AT & 0.0256 & Positive \\
\hline GSE17536 & Colon cancer & 1556006_S_AT & 0.0271 & Negative \\
\hline GSE11969 & Lung cancer & 21556 & 0.0284 & Negative \\
\hline GSE17538 & Colon cancer & 1556006_S_AT & 0.0289 & Negative \\
\hline GSE30682 & Breast cancer & ILMN_1775058 & 0.033 & Positive \\
\hline GSE30929 & Liposarcoma & 208865_AT & 0.0461 & Negative \\
\hline \multicolumn{5}{|c|}{ Survival profile of CSNK1D across available datasets (with $p<0.05$ ) } \\
\hline GEO dataset & Cancer type & GENE (Probe ID) & P-value & Effect sign \\
\hline GSE131213 & Lung cancer & A_23_P207896 & 0.000863 & Negative \\
\hline GSE25025 & Breast cancer & 208774_AT & 0.00101 & Positive \\
\hline GSE39671 & Chronic lymphocytic leukemia & 207945_S_AT & 0.00382 & Positive \\
\hline GSE22226 & Breast cancer & 41429 & 0.00432 & Positive \\
\hline GSE22762 & Chronic lymphocytic leukemia & 208774_AT & 0.0122 & Positive \\
\hline GSE31210 & Lung cancer & 207945_S_AT & 0.0162 & Negative \\
\hline GSE25065 & Breast cancer & 208774_AT & 0.023 & Positive \\
\hline GSE18166 & Astrocytic gliomas & 37202 & 0.0268 & Positive \\
\hline GSE13041 & Glioblastoma & 208774_AT & 0.0272 & Negative \\
\hline \multicolumn{5}{|c|}{ Survival profile of CSNK1E across available datasets (with $p<0.05$ ) } \\
\hline GEO dataset & Cancer type & GENE (Probe ID) & P-value & Effect sign \\
\hline GSE10846 & Diffuse large b cell lymphoma & 226858_AT & $1.39 \mathrm{e}-05$ & Negative \\
\hline GSE1456 & Breast cancer & 222015_AT & 0.002 & Negative \\
\hline GSE11969 & Lung cancer & 13708 & 0.016 & Negative \\
\hline GSE4271 & High-grade glioma & 202332_AT & 0.0281 & Positive \\
\hline GSE24450 & Breast cancer & ILMN_1708858 & 0.0296 & Negative \\
\hline GSE18166 & Astrocytic gliomas & 28635 & 0.0303 & Positive \\
\hline GSE31210 & Lung cancer & 202332_AT & 0.032 & Positive \\
\hline GSE39671 & Chronic lymphocytic leukemia & 234943_AT & 0.0478 & Positive \\
\hline
\end{tabular}


glioma) out of 9 studies ( 3 correlated negatively) and for CK1 $1 \varepsilon$ there was a rather mixed picture with 4 positive (glioma, lung cancer and leukemia) and 4 negative correlating studies (B cell lymphoma, breast cancer and lung cancer) (Table 2 and Figure 3B). The higher number of significant studies showing a positive prognosis for patients with high levels of CK1 $\alpha$ expression hints to the postulated function as tumor suppressor in some cancers whereas the mixed pattern for CK $1 \delta$ and especially CK $1 \varepsilon$ depicts a context dependent function of the isoforms being either pro- or anti-tumorigenic.

However, it remains uncertain whether the CK1 $\delta$ and $\varepsilon$ isoforms represent drivers of tumorigenesis or if their disregulation and altered expression is rather the consequence of other cellular oncogenic events. Therefore critical genetic validation models should be developed in order to prove the concept of CK1 isoforms as important regulators in tumorigenesis besides the development of specific pharmacological inhibitors.

\section{Pharmacological inhibition of CK1 isoforms}

Due to the above described involvement of CK1 isoforms in tumorigenesis pharmacological inhibition of CK1 familiy members could be of interest for targeted cancer therapy. However, the development of isoform specific inhibitors seems to be a demanding task since the first known inhibitors like the ATP-competitive type I inhibitors CKI-7 or IC261 are not highly specific and show a rather broad effectivity against CK1 isoforms with a predominance for $\delta$ and $\varepsilon$. IC261 showed activity against pancreatic tumors in a xenograft mouse model [89] as well as in a MYC-driven neuroblastoma model [110]. Meanwhile, it is known that IC261 also efficiently inhibits the polymerization of microtubules in a CK1 independent manner, Therefore it is questionable whether the anti-tumorigenic effects are due to selective inhibition of CK1 $\delta$. D4476, another CK1 inhibitor which shows some selectivity towards the $\delta$ isoform, was successfully applied in a leukemia mouse model causing the elimination of the tumor cells. However, since the $\alpha$ isoform seems to be dominant for the described mechanism in this model by Jaras et al., the effects measured with D4476 might result due to the inhibition of additional susceptible isoforms and drug targets like CK1 $\delta$ or the TGF- $\beta$ type-I receptor ALK5. Huart et. al reported a novel inhibitor belonging to the class of pyrazolo-pyridine analogues that strongly inhibits CK1 $\delta$ in conjunction with CHK1 thereby activating the p53 pathway and inducing apoptosis in A375 melanoma cells. However, a similar analog described in the same study but lacking the CHK1 inhibitory function showed no apoptosis induction in A375 cells [61]. Further developments were undertaken by Bibian et al. in order to generate highly specific CK $1 \delta / \varepsilon$ inhibitors resulting in a series of purine scaffold inhibitors (SR-1277, SR-2890, SR-3029) with $\mathrm{IC}_{50}$ values in the low nanomolar range. These inhibitors were also highly potent in inhibiting A375 melanoma cell growth in a MTT viability assay. Interestingly, the inhibition with less specific inhibitors like D4476 or PF670462 did not show these inhibitory effects, proposing a better cell penetration of the SR inhibitors and better efficacy [111]. In order to exclude any of the remaining very few off-targets to be the main originators of the effects on A375 melanoma cell viability, genetic tests (like knockdowns or knockouts) targeting CK1 isoforms should be performed. Further studies will be needed to determine the cellular efficacy and specificity of these interesting novel CK1 inhibitors. For detailed further information about the development of additional CK1 inhibitors we refer to the excellent review by Knippschild et al. [90].

\section{Conclusions}

CK1 isoforms can influence the development and progression of tumor cells, although they seem to have different effects depending on the tumor types. Their ability to regulate several important signaling molecules is modulated in different types of tumors. This suggests that CK1 isoforms might be suitable targets for clinical intervention. Especially their ability to regulate p53 and Wnt-signaling, cell cycle progression and apoptosis induction makes them attractive targets in tumor therapy. Since the CK1 isoforms seems to have sometimes opposing roles in different tumor types it will be essential in future to validate the effect of specific CK1 isoforms in defined tumor types on cell cycle progression and signal transduction. Since several kinase inhibitors are in preclinical development there is hope that, among these, some of the most effective inhibitors could delay or inhibit tumor progression.

Competing interests

The authors declare that they have no competing interests.

\section{Authors' contributions}

BS and TS wrote the manuscript. Database analyses and figure preparation were done by TS. Tables were created by BS and TS. Both authors read and approved the final manuscript.

\section{Acknowledgements}

This work was supported by the Deutsche Krebshilfe (110210) and the intramural funding program of the medical faculty of the University of Tübingen (fortüne 2198-0-0).

Received: 16 May 2014 Accepted: 26 September 2014

Published: 11 October 2014

\section{References}

1. Knippschild U, Gocht A, Wolff S, Huber N, Löhler J, Stöter M: The casein kinase 1 family: participation in multiple cellular processes in eukaryotes. Cell Signal 2005, 17:675-689.

2. Knippschild U, Wolff S, Giamas G, Brockschmidt C, Wittau M, Wörl PU, Eismann T, Stöter M, Würl PU, Stöter M: The role of the casein kinase 1 (CK1) family in different signaling pathways linked to cancer development. Onkologie 2005, 28:508-514. 
3. Gross SD, Anderson RA: Casein kinase I: spatial organization and positioning of a multifunctional protein kinase family. Cell Signal 1998, 10:699-711.

4. Price $\mathrm{MA}: \mathrm{CKI}$, there's more than one: casein kinase I family members in Wnt and Hedgehog signaling. Genes Dev 2006, 20:399-410.

5. Cheong JK, Virshup DM: Casein kinase 1: Complexity in the family. Int Biochem Cell Biol 2011, 43:465-469.

6. Fish KJ, Cegielska A, Getman ME, Landes GM, Virshup DM: Isolation and characterization of human casein kinase I epsilon (CKI), a novel member of the CKI gene family. J Biol Chem 1995, 270:14875-14883.

7. Greer YE, Rubin JS: Casein kinase 1 delta functions at the centrosome to mediate Wnt-3a-dependent neurite outgrowth. J Cell Biol 2011. 192:993-1004

8. Carvalho G, Le Guelte A, Demian C, Vazquez A, Gavard J, Bidère N: Interplay between BCL10, MALT1 and IkappaBalpha during T-cell-receptormediated NFkappaB activation. J Cell Sci 2010, 123(Pt 14):2375-2380.

9. Desagher S, Osen-Sand A, Montessuit S, Magnenat E, Vilbois F, Hochmann A, Journot L, Antonsson B, Martinou JC: Phosphorylation of bid by casein kinases I and II regulates its cleavage by caspase 8. Mo/ Cell 2001, 8:601-611.

10. Alappat EC, Feig C, Boyerinas B, Volkland J, Samuels M, Murmann AE, Thorburn A, Kidd VJ, Slaughter CA, Osborn SL, Winoto A, Tang W-J, Peter ME: Phosphorylation of FADD at serine 194 by CKlalpha regulates its nonapoptotic activities. Mol Cell 2005, 19:321-332

11. Huart A-S, MacLaine NJ, Meek DW, Hupp TR: CK1alpha plays a central role in mediating MDM2 control of p53 and E2F-1 protein stability. J Biol Chem 2009, 284:32384-32394.

12. Bischof J, Randoll S-J, Süßner N, Henne-Bruns D, Pinna LA, Knippschild U: CK1 $\delta$ kinase activity is modulated by Chk1-mediated phosphorylation. PLoS One 2013, 8:e68803.

13. Cruciat C-M, Dolde C, de Groot REA, Ohkawara B, Reinhard C, Korswagen $\mathrm{HC}$, Niehrs $\mathrm{C}$ : RNA helicase DDX3 is a regulatory subunit of casein kinase 1 in Wnt- $\beta$-catenin signaling. Science 2013, 339:1436-1441. doi:10.1038/ onc.2013.564.

14. Yim DGR, Ghosh S, Guy GR, Virshup DM: Casein kinase 1 regulates Sprouty2 in FGF-ERK signaling. Oncogene 2014.

15. Price MA, Kalderon D: Proteolysis of the Hedgehog signaling effector Cubitus interruptus requires phosphorylation by Glycogen Synthase Kinase 3 and Casein Kinase 1. Cell 2002, 108:823-835.

16. Rodriguez N, Yang J, Hasselblatt K, Liu S, Zhou Y, Rauh-Hain JA, Ng S-K, Choi P-W, Fong W-P, Agar NYR, Welch WR, Berkowitz RS, Ng S-W: Casein kinase I epsilon interacts with mitochondrial proteins for the growth and survival of human ovarian cancer cells. EMBO Mol Med 2012, 4:952-963.

17. Xu F, Wang Y-L, Chang J-J, Du S-C, Diao L, Jiang N, Wang H-J, Ma D, Zhang $\mathrm{J}$ : Mammalian sterile 20 -like kinase $1 / 2$ inhibits the $W \mathrm{nt} / \beta$-catenin signalling pathway by directly binding casein kinase $1 \varepsilon$. Biochem J 2014 458:159-169.

18. Bidère N, Ngo VN, Lee J, Collins C, Zheng L, Wan F, Davis RE, Lenz G, Anderson DE, Arnoult D, Vazquez A, Sakai K, Zhang J, Meng Z, Veenstra TD Staudt LM, Lenardo MJ: Casein kinase 1alpha governs antigen-receptorinduced NF-kappaB activation and human lymphoma cell survival. Nature 2009, 458:92-96.

19. Wang $Y$, Hu L, Tong $X$, Ye $X$ : Casein kinase $1 Y 1$ inhibits the RIG-I/TLR signaling pathway through phosphorylating $\mathrm{p} 65$ and promoting its degradation. J Immunol 2014, 192:1855-1861.

20. Wu S, Chen L, Becker A, Schonbrunn E, Chen J: Casein kinase 1a regulates an MDMX intramolecular interaction to stimulate p53 binding. Mol Cell Biol 2012, 32:4821-4832.

21. Milne DM, Palmer RH, Campbell DG, Meek DW: Phosphorylation of the p53 tumour-suppressor protein at three $\mathrm{N}$-terminal sites by a novel casein kinase I-like enzyme. Oncogene 1992, 7:1361-1369.

22. Rena G, Bain J, Elliott M, Cohen P: D4476, a cell-permeant inhibitor of CK1, suppresses the site-specific phosphorylation and nuclear exclusion of FOXO1a. EMBO Rep 2004, 5:60-65.

23. Magliozzi R, Low TY, Weijts BGMW, Cheng T, Spanjaard E, Mohammed S, van Veen A, Ovaa H, de Rooij J, Zwartkruis FJT, Bos JL, de Bruin A, Heck AJR, Guardavaccaro D: Control of epithelial cell migration and invasion by the IKK $\beta$ - and CK1a-mediated degradation of RAPGEF2. Dev Cell 2013, 27:574-585

24. Waddell DS, Liberati NT, Guo X, Frederick JP, Wang X-F: Casein kinase lepsilon plays a functional role in the transforming growth factor-beta signaling pathway. J Biol Chem 2004, 279:29236-29246.
25. Rubinfeld B, Tice DA, Polakis P: Axin-dependent phosphorylation of the adenomatous polyposis coli protein mediated by casein kinase 1epsilon. J Biol Chem 2001, 276:39037-39045

26. Shen T, Liu Y, Cseresnyés Z, Hawkins A, Randall WR, Schneider MF: Activityand calcineurin-independent nuclear shuttling of NFATc1, but not NFATc3, in adult skeletal muscle fibers. Mol Biol Cell 2006, 17:1570-1582.

27. Klein TJ, Jenny A, Djiane A, Mlodzik M: CKlepsilon/discs overgrown promotes both Wnt-Fz/beta-catenin and Fz/PCP signaling in Drosophila. Curr Biol 2006, 16:1337-1343.

28. Venerando A, Girardi C, Ruzzene M, Pinna LA: Pyrvinium pamoate does not activate protein kinase CK1, but promotes Akt/PKB down-regulation and GSK3 activation. Biochem J 2013, 452:131-137.

29. Del Valle-Pérez $B$, Arqués $O$, Vinyoles $M$, de Herreros AG, Duñach $M$ : Coordinated action of CK1 isoforms in canonical Wnt signaling. Mol Cell Biol 2011, 31:2877-2888.

30. Flotow H, Graves PR, Wang AQ, Fiol CJ, Roeske RW, Roach PJ: Phosphate groups as substrate determinants for casein kinase I action. J Biol Chem 1990, 265:14264-14269.

31. McKenzie JAG, Riento K, Ridley AJ: Casein kinase I epsilon associates with and phosphorylates the tight junction protein occludin. FEBS Lett 2006, 580:2388-2394.

32. Sillibourne JE, Milne DM, Takahashi M, Ono Y, Meek DW: Centrosomal anchoring of the protein kinase CK1delta mediated by attachment to the large, coiled-coil scaffolding protein CG-NAP/AKAP450. J Mol Biol 2002, 322:785-797.

33. Wolff S, Stöter M, Giamas G, Piesche M, Henne-Bruns D, Banting G, Knippschild U: Casein kinase 1 delta (CK1delta) interacts with the SNARE associated protein snapin. FEBS Lett 2006, 580:6477-6484.

34. Wolff S, Xiao Z, Wittau M, Süssner N, Stöter M, Knippschild U: Interaction of casein kinase 1 delta (CK1 delta) with the light chain LC2 of microtubule associated protein 1A (MAP1A). Biochim Biophys Acta 2005, 1745:196-206.

35. Behrend L, Stöter M, Kurth M, Rutter G, Heukeshoven J, Deppert W, Knippschild U: Interaction of casein kinase 1 delta (CK1delta) with postGolgi structures, microtubules and the spindle apparatus. Eur J Cell Biol 2000, 79:240-251.

36. Yin H, Laguna KA, Li G, Kuret J: Dysbindin structural homologue CK1BP is an isoform-selective binding partner of human casein kinase-1. Biochemistry 2006, 45:5297-5308.

37. Zemp I, Wandrey F, Rao S, Ashiono C, Wyler E, Montellese C, Kutay U: CK1 $\delta$ and $C K 1 \varepsilon$ are components of human $40 S$ subunit precursors required for cytoplasmic 40S maturation. J Cell Sci 2014, 127(Pt 6):1242-1253.

38. Brockman JL, Gross SD, Sussman MR, Anderson RA: Cell cycle-dependent localization of casein kinase I to mitotic spindles. Proc Natl Acad Sci U S A 1992, 89:9454-9458.

39. Gross SD, Simerly C, Schatten G, Anderson RA: A casein kinase I isoform is required for proper cell cycle progression in the fertilized mouse oocyte. J Cell Sci 1997, 110(Pt 2):3083-3090.

40. Wang L, Lu A, Zhou H-X, Sun R, Zhao J, Zhou C-J, Shen J-P, Wu S-N, Liang C-G: Casein kinase 1 alpha regulates chromosome congression and separation during mouse oocyte meiotic maturation and early embryo development. PLoS One 2013, 8:e63173.

41. Duan S, Skaar JR, Kuchay S, Toschi A, Kanarek N, Ben-Neriah Y, Pagano M: mTOR generates an auto-amplification loop by triggering the $\beta \operatorname{TrCP}$ and CK1a-dependent degradation of DEPTOR. Mol Cell 2011, 44:317-324.

42. Izeradjene K, Douglas L, Delaney AB, Houghton JA: Casein kinase I attenuates tumor necrosis factor-related apoptosis-inducing ligandinduced apoptosis by regulating the recruitment of fas-associated death domain and procaspase- 8 to the death-inducing signaling complex. Cancer Res 2004, 64:8036-8044.

43. Zhao Y, Qin S, Atangan LI, Molina Y, Okawa Y, Arpawong HT, Ghosn C, Xiao J-H, Vuligonda V, Brown G, Chandraratna RAS: Casein kinase 1alpha interacts with retinoid $X$ receptor and interferes with agonist-induced apoptosis. J Biol Chem 2004, 279:30844-30849.

44. Sinnberg T, Menzel M, Kaesler S, Biedermann T, Sauer B, Nahnsen S, Schwarz M, Garbe C, Schittek B: Suppression of casein kinase 1alpha in melanoma cells induces a switch in beta-catenin signaling to promote metastasis. Cancer Res 2010, 70:6999-7009.

45. Tobin AB: Are we beta-ARKing up the wrong tree? Casein kinase 1 alpha provides an additional pathway for GPCR phosphorylation. Trends Pharmacol Sci 2002, 23:337-343. 
46. Waugh MG, Challiss RA, Berstein G, Nahorski SR, Tobin AB: Agonist-induced desensitization and phosphorylation of $\mathrm{m} 1$-muscarinic receptors. Biochem J 1999, 338(Pt 1):175-183.

47. Okamura H, Garcia-Rodriguez C, Martinson H, Qin J, Virshup DM, Rao A: A conserved docking motif for CK1 binding controls the nuclear localization of NFAT1. Mol Cell Biol 2004, 24:4184-4195.

48. Dejmek J, Säfholm A, Kamp Nielsen C, Andersson T, Leandersson K: Wnt-5a/ $\mathrm{Ca} 2+-$ induced NFAT activity is counteracted by Wnt-5a/Yes-Cdc42casein kinase 1alpha signaling in human mammary epithelial cells. Mol Cell Biol 2006, 26:6024-6036.

49. Vielhaber E, Eide E, Rivers A, Gao ZH, Virshup DM: Nuclear entry of the circadian regulator $\mathrm{mPER} 1$ is controlled by mammalian casein kinase I epsilon. Mol Cell Biol 2000, 20:4888-4899.

50. Hirota T, Lee JW, Lewis WG, Zhang EE, Breton G, Liu X, Garcia M, Peters EC, Etchegaray J-P, Traver D, Schultz PG, Kay SA: High-throughput chemical screen identifies a novel potent modulator of cellular circadian rhythms and reveals CKla as a clock regulatory kinase. PLOS Biol 2010, 8:e1000559.

51. Walton KM, Fisher K, Rubitski D, Marconi M, Meng Q-J, Sládek M, Adams J, Bass M, Chandrasekaran R, Butler T, Griffor M, Rajamohan F, Serpa M, Chen Y, Claffey M, Hastings M, Loudon A, Maywood E, Ohren J, Doran A, Wager $\Pi$ : Selective inhibition of casein kinase 1 epsilon minimally alters circadian clock period. J Pharmacol Exp Ther 2009, 330:430-439.

52. Harms E, Young MW, Saez L: CK1 and GSK3 in the Drosophila and mammalian circadian clock. Novartis Found Symp 2003, 253(102-9):277-284. discussion.

53. Meng Q-J, Maywood ES, Bechtold DA, Lu W-Q, Li J, Gibbs JE, Dupré SM, Chesham JE, Rajamohan F, Knafels J, Sneed B, Zawadzke LE, Ohren JF, Walton KM, Wager TT, Hastings MH, Loudon ASI: Entrainment of disrupted circadian behavior through inhibition of casein kinase 1 (CK1) enzymes. Proc Natl Acad Sci U S A 2010, 107:15240-15245.

54. Behrend L, Milne DM, Stöter M, Deppert W, Campbell LE, Meek DW, Knippschild U: IC261, a specific inhibitor of the protein kinases casein kinase 1-delta and -epsilon, triggers the mitotic checkpoint and induces p53-dependent postmitotic effects. Oncogene 2000, 19:5303-5313.

55. Stöter M, Bamberger AM, Aslan B, Kurth M, Speidel D, Löning T, Frank HG, Kaufmann P, Löhler J, HenneBruns D, Deppert W, Knippschild U: Inhibition of casein kinase I delta alters mitotic spindle formation and induces apoptosis in trophoblast cells. Oncogene 2005, 24:7964-7975.

56. Greer YE, Westlake CJ, Gao B, Bharti K, Shiba Y, Xavier CP, Pazour GJ, Yang Y, Rubin JS: Casein kinase $1 \delta$ functions at the centrosome and Golgi to promote ciliogenesis. Mol Biol Cell 2014, 25:1629-1640.

57. Hanger DP, Byers HL, Wray S, Leung K-Y, Saxton MJ, Seereeram A, Reynolds $\mathrm{CH}$, Ward MA, Anderton $\mathrm{BH}$ : Novel phosphorylation sites in tau from Alzheimer brain support a role for casein kinase 1 in disease pathogenesis. J Biol Chem 2007, 282:23645-23654

58. León-Espinosa G, García E, García-Escudero V, Hernández F, Defelipe J, Avila $\mathrm{J}$ : Changes in tau phosphorylation in hibernating rodents. J Neurosci Res 2013, 91:954-962.

59. Li G, Yin H, Kuret J: Casein kinase 1 delta phosphorylates tau and disrupts its binding to microtubules. J Biol Chem 2004, 279:15938-15945.

60. Johnson $A E$, Chen J-S, Gould KL: CK1 is required for a mitotic checkpoint that delays cytokinesis. Curr Biol 2013, 23:1920-1926.

61. Huart A-S, Saxty B, Merritt A, Nekulova M, Lewis S, Huang Y, Vojtesek B, Kettleborough C, Hupp TR: A Casein kinase 1/Checkpoint kinase 1 pyrazolo-pyridine protein kinase inhibitor as novel activator of the p53 pathway. Bioorg Med Chem Lett 2013, 23:5578-5585.

62. Bernatik O, Ganji RS, Dijksterhuis JP, Konik P, Cervenka I, Polonio T, Krejci P, Schulte G, Bryja V: Sequential activation and inactivation of Dishevelled in the Wnt/beta-catenin pathway by casein kinases. J Biol Chem 2011, 286:10396-10410.

63. Liu C, Li Y, Semenov M, Han C, Baeg GH, Tan Y, Zhang Z, Lin X, He X: Control of beta-catenin phosphorylation/degradation by a dual-kinase mechanism. Cell 2002, 108:837-847.

64. Amit S, Hatzubai A, Birman Y, Andersen JS, Ben-Shushan E, Mann M, Ben-Neriah Y, Alkalay l: Axin-mediated CKI phosphorylation of beta-catenin at Ser 45: a molecular switch for the Wnt pathway. Genes Dev 2002, 16:1066-1076.

65. Carreras Puigvert J, Von Stechow L, Siddappa R, Pines A, Bahjat M, Haazen LCJM, Olsen JV, Vrieling H, Meerman JHN, Mullenders LHF, Van De Water B, Danen EHJ: Systems biology approach identifies the kinase Csnk1a1 as a regulator of the DNA damage response in embryonic stem cells. Sci Signal 2013, 6:ra5.
66. Ha N-C, Tonozuka T, Stamos JL, Choi H-J, Weis WI: Mechanism of phosphorylation-dependent binding of APC to beta-catenin and its role in beta-catenin degradation. Mol Cell 2004, 15:511-521.

67. Hämmerlein A, Weiske J, Huber O: A second protein kinase CK1-mediated step negatively regulates Wnt signalling by disrupting the lymphocyte enhancer factor-1/beta-catenin complex. Cell Mol Life Sci 2005, 62:606-618.

68. Knippschild U, Milne DM, Campbell LE, DeMaggio AJ, Christenson E, Hoekstra MF, Meek DW: p53 is phosphorylated in vitro and in vivo by the delta and epsilon isoforms of casein kinase 1 and enhances the level of casein kinase 1 delta in response to topoisomerase-directed drugs. Oncogene 1997, 15:1727-1736.

69. Dumaz N, Milne DM, Meek DW: Protein kinase CK1 is a p53-threonine 18 kinase which requires prior phosphorylation of serine 15. FEBS Lett 1999, 463:312-316.

70. Winter M, Milne D, Dias S, Kulikov R, Knippschild U, Blattner C, Meek D: Protein kinase CK1delta phosphorylates key sites in the acidic domain of murine double-minute clone 2 protein (MDM2) that regulate p53 turnover. Biochemistry 2004, 43:16356-16364.

71. Elyada E, Pribluda A, Goldstein RE, Morgenstern Y, Brachya G, Cojocaru G, Snir-Alkalay I, Burstain I, Haffner-Krausz R, Jung S, Wiener Z, Alitalo K, Oren M, Pikarsky E, Ben-Neriah Y: CKla ablation highlights a critical role for p53 in invasiveness control. Nature 2011, 470:409-413.

72. Sarasqueta AF, Forte G, Corver WE, de Miranda NF, Ruano D, van Eijk R, Oosting J, Tollenaar RAEM, van Wezel T, Morreau H: Integral analysis of p53 and its value as prognostic factor in sporadic colon cancer. BMC Cancer 2013, 13:277.

73. Järås $M$, Miller $P G$, Chu LP, Puram RV, Fink EC, Schneider RK, Al-Shahrour F, Peña P, Breyfogle LJ, Hartwell KA, McConkey ME, Cowley GS, Root DE, Kharas MG, Mullally A, Ebert BL: Csnk1a1 inhibition has p53-dependent therapeutic efficacy in acute myeloid leukemia. J Exp Med 2014, 211:605-612.

74. Chen L, Li C, Pan Y, Chen J: Regulation of p53-MDMX interaction by casein kinase 1 alpha. Mol Cell Biol 2005, 25:6509-6520.

75. Venerando A, Marin O, Cozza G, Bustos VH, Sarno S, Pinna LA: Isoform specific phosphorylation of p53 by protein kinase CK1. Cell Mol Life Sci 2010, 67:1105-1118.

76. Inuzuka H, Tseng A, Gao D, Zhai B, Zhang Q, Shaik S, Wan L, Ang XL, Mock C, Yin H, Stommel JM, Gygi S, Lahav G, Asara J, Xiao Z-XJ, Kaelin WG, Harper JW, Wei W: Phosphorylation by casein kinase I promotes the turnover of the Mdm2 oncoprotein via the SCF(beta-TRCP) ubiquitin ligase. Cancer Cell 2010, 18:147-159.

77. Zhang P, Bill K, Liu J, Young E, Peng T, Bolshakov S, Hoffman A, Song Y, Demicco EG, Terrada DL, Creighton CJ, Anderson ML, Lazar AJ, Calin GG, Pollock RE, Lev D: MiR-155 is a liposarcoma oncogene that targets casein kinase-1 $\alpha$ and enhances $\beta$-catenin signaling. Cancer Res 2012, 72:1751-1762.

78. Lee C, Etchegaray JP, Cagampang FR, Loudon AS, Reppert SM: Posttranslational mechanisms regulate the mammalian circadian clock. Cell 2001, 107:855-867.

79. Yong TJ, Gan YY, Toh BH, Sentry JW: Human CKlalpha(L) and CKlalpha(S) are encoded by both 2.4- and 4. 2-kb transcripts, the longer containing multiple RNA-destablising elements. Biochim Biophys Acta 2000, 1492:425-433.

80. Green CL, Bennett GS: Identification of four alternatively spliced isoforms of chicken casein kinase I alpha that are all expressed in diverse cell types. Gene 1998, 216:189-195

81. Fu Z, Green CL, Bennett GS: Relationship between casein kinase I isoforms and a neurofilament-associated kinase. J Neurochem 1999, 73:830-838.

82. Budini M, Jacob G, Jedlicki A, Pérez C, Allende CC, Allende JE: Autophosphorylation of carboxy-terminal residues inhibits the activity of protein kinase CK1alpha. J Cell Biochem 2009, 106:399-408.

83. Cegielska A, Gietzen KF, Rivers A, Virshup DM: Autoinhibition of casein kinase I epsilon (CKI epsilon) is relieved by protein phosphatases and limited proteolysis. J Biol Chem 1998, 273:1357-1364.

84. Graves PR, Roach PJ: Role of $\mathrm{COOH}$-terminal phosphorylation in the regulation of casein kinase I delta. J Biol Chem 1995, 270:21689-21694.

85. Longenecker KL, Roach PJ, Hurley TD: Crystallographic studies of casein kinase I delta toward a structural understanding of auto-inhibition. Acta Crystallogr D Biol Crystallogr 1998, 54(Pt 3):473-475.

86. Thorne CA, Hanson AJ, Schneider J, Tahinci E, Orton D, Cselenyi CS, Jernigan KK, Meyers KC, Hang BI, Waterson AG, Kim K, Melancon B, Ghidu 
VP, Sulikowski GA, LaFleur B, Salic A, Lee LA, Miller DM 3rd, Lee E, Miller DM: Small-molecule inhibition of Wnt signaling through activation of casein kinase 1a. Nat Chem Biol 2010, 6:829-836.

87. Maritzen T, Lohler J, Deppert W, Knippschild U: Casein kinase I delta (CKIdelta) is involved in lymphocyte physiology. Eur J Cell Biol 2003, 82:369-378.

88. Masuda K, Ono M, Okamoto M, Morikawa W, Otsubo M, Migita T, Tsuneyoshi M, Okuda H, Shuin T, Naito S, Kuwano M: Downregulation of Cap43 gene by von Hippel-Lindau tumor suppressor protein in human renal cancer cells. Int J Cancer 2003, 105:803-810.

89. Brockschmidt C, Hirner H, Huber N, Eismann T, Hillenbrand A, Giamas G, Radunsky B, Ammerpohl O, Bohm B, Henne-Bruns D, Kalthoff H, Leithäuser F, Trauzold A, Knippschild U, Leithäuser F: Anti-apoptotic and growthstimulatory functions of CK1 delta and epsilon in ductal adenocarcinoma of the pancreas are inhibited by IC261 in vitro and in vivo. Gut 2008, 57:799-806

90. Knippschild U, Krüger M, Richter J, Xu P, García-Reyes B, Peifer C, Halekotte J, Bakulev V, Bischof J: The CK1 Family: Contribution to Cellular Stress Response and Its Role in Carcinogenesis. Front Oncol 2014, 4:96.

91. Sun D, Zhou M, Kowolik CM, Trisal V, Huang Q, Kernstine KH, Lian F, Shen B: Differential expression patterns of capping protein, protein phosphatase 1 , and casein kinase 1 may serve as diagnostic markers for malignant melanoma. Melanoma Res 2011, 21:335-343.

92. Fuja TJ, Lin F, Osann KE, Bryant PJ: Somatic mutations and altered expression of the candidate tumor suppressors CSNK1 epsilon, DLG1, and EDD/hHYD in mammary ductal carcinoma. Cancer Res 2004, 64:942-951.

93. Tsai I-C, Woolf M, Neklason DW, Branford WW, Yost HJ, Burt RW, Virshup DM: Disease-associated casein kinase I delta mutation may promote adenomatous polyps formation via a Wnt/beta-catenin independent mechanism. Int J Cancer 2007, 120:1005-1012

94. Gao J, Aksoy BA, Dogrusoz U, Dresdner G, Gross B, Sumer SO, Sun Y, Jacobsen A, Sinha R, Larsson E, Cerami E, Sander C, Schultz N: ntegrative analysis of complex cancer genomics and clinical profiles using the cBioPortal. Sci Signal 2013, 6:pl1.

95. Cerami E, Gao J, Dogrusoz U, Gross BE, Sumer SO, Aksoy BA, Jacobsen A, Byrne CJ, Heuer ML, Larsson E, Antipin Y, Reva B, Goldberg AP, Sander C, Schultz N: The cBio cancer genomics portal: an open platform for exploring multidimensional cancer genomics data. Cancer Discov 2012, 2:401-404.

96. Antonov AV, Krestyaninova M, Knight RA, Rodchenkov I, Melino G, Barlev NA: PPISURV: a novel bioinformatics tool for uncovering the hidden role of specific genes in cancer survival outcome. Oncogene 2014, 33:1621-1628.

97. Kim SY, Dunn IF, Firestein R, Gupta P, Wardwell L, Repich K, Schinzel AC, Wittner B, Silver SJ, Root DE, Boehm JS, Ramaswamy S, Lander ES, Hahn WC: CK1epsilon is required for breast cancers dependent on beta-catenin activity. PLoS One 2010, 5:e8979.

98. Lin S-H, Lin Y-M, Yeh C-M, Chen C-J, Chen M-W, Hung H-F, Yeh K-T, Yang S-F: Casein kinase 1 epsilon expression predicts poorer prognosis in low T-stage oral cancer patients. Int J Mol Sci 2014, 15:2876-2891.

99. Cheong JK, Nguyen TH, Wang H, Tan P, Voorhoeve PM, Lee SH, Virshup DM: IC261 induces cell cycle arrest and apoptosis of human cancer cells via CK1 $\delta / \varepsilon$ and Wnt/ $\beta$-catenin independent inhibition of mitotic spindle formation. Oncogene 2011, 30:2558-2569.

100. Hirner H, Günes C, Bischof J, Wolff S, Grothey A, Kühl M, Oswald F, Wegwitz F, Bösl MR, Trauzold A, Henne-Bruns D, Peifer C, Leithäuser F, Deppert W, Knippschild U: Impaired CK1 delta activity attenuates SV40-induced cellular transformation in vitro and mouse mammary carcinogenesis in vivo. PLoS One 2012, 7:e29709.

101. Sinnberg T, Menzel M, Ewerth D, Sauer B, Schwarz M, Schaller M, Garbe C, Schittek $B$ : $\beta$-Catenin signaling increases during melanoma progression and promotes tumor cell survival and chemoresistance. PLOS One 2011, 6:e23429.

102. Vaid M, Prasad R, Sun Q, Katiyar SK: Silymarin Targets ?-Catenin Signaling in Blocking Migration/Invasion of Human Melanoma Cells. PLoS One 2011, 6:e23000.

103. Chien AJ, Moore EC, Lonsdorf AS, Kulikauskas RM, Rothberg BG, Berger AJ, Major MB, Hwang ST, Rimm DL, Moon RT: Activated Wnt/beta-catenin signaling in melanoma is associated with decreased proliferation in patient tumors and a murine melanoma model. Proc Natl Acad Sci U S A 2009, 106:1193-1198.
104. Lucero OM, Dawson DW, Moon RT, Chien AJ: A re-evaluation of the "oncogenic" nature of Wnt/beta-catenin signaling in melanoma and other cancers. Curr Oncol Rep 2010, 12:314-318.

105. Chien AJ, Haydu LE, Biechele TL, Kulikauskas RM, Rizos H, Kefford RF, Scolyer RA, Moon RT, Long GV: Targeted BRAF inhibition impacts survival in melanoma patients with high levels of Wnt/ $\beta$-catenin signaling. PLoS One 2014, 9:e94748.

106. Yu DH, Macdonald J, Liu G, Lee AS, Ly M, Davis T, Ke N, Zhou D, Wong Staal F, Li QX: Pyrvinium targets the unfolded protein response to hypoglycemia and its anti-tumor activity is enhanced by combination therapy. PLoS One 2008, 3:e3951.

107. Deng L, Lei Y, Liu R, Li J, Yuan K, Li Y, Chen Y, Liu Y, Lu Y, Edwards CK, Huang C, Wei Y: Pyrvinium targets autophagy addiction to promote cancer cell death. Cell Death Dis 2013, 4:e614.

108. Zou F-Y, Xie H-L, Chen Z-C, He C-M, Guan Y-J, Li YJ: [Effect of HLCDG1 gene transfection on growth of lung carcinoma cells]. Ai Zheng 2003, 22:1121-1126.

109. Pribluda A, Elyada E, Wiener Z, Hamza H, Goldstein RE, Biton M, Burstain I, Morgenstern Y, Brachya G, Billauer H, Biton S, Snir-Alkalay I, Vucic D, Schlereth K, Mernberger M, Stiewe T, Oren M, Alitalo K, Pikarsky E, Ben-Neriah Y: A senescence-inflammatory switch from cancer-inhibitory to cancerpromoting mechanism. Cancer Cell 2013, 24:242-256.

110. Toyoshima M, Howie HL, Imakura M, Walsh RM, Annis JE, Chang AN, Frazier J, Chau BN, Loboda A, Linsley PS, Cleary MA, Park JR, Grandori C: Functional genomics identifies therapeutic targets for MYC-driven cancer. Proc Natl Acad Sci U S A 2012, 109:9545-9550.

111. Bibian M, Rahaim RJ, Choi JY, Noguchi Y, Schürer S, Chen W, Nakanishi S, Licht K, Rosenberg LH, Li L, Feng Y, Cameron MD, Duckett DR, Cleveland JL, Roush WR: Development of highly selective casein kinase $1 \delta / 1 \varepsilon(C K 1 \delta / \varepsilon)$ inhibitors with potent antiproliferative properties. Bioorg Med Chem Lett 2013, 23:4374-4380.

doi:10.1186/1476-4598-13-231

Cite this article as: Schittek and Sinnberg: Biological functions of casein kinase 1 isoforms and putative roles in tumorigenesis. Molecular Cancer 2014 13:231

\section{Submit your next manuscript to BioMed Central and take full advantage of:}

- Convenient online submission

- Thorough peer review

- No space constraints or color figure charges

- Immediate publication on acceptance

- Inclusion in PubMed, CAS, Scopus and Google Scholar

- Research which is freely available for redistribution 